\title{
IMPLIKASI HUKUM UNDANG-UNDANG NO. 2 TAHUN 2020 TERHADAP PENCEGAHAN DAN PENANGANAN POTENSI RISIKO LIKUIDITAS BANK PERKREDITAN RAKYAT MELALUI PINJAMAN LIKUIDITAS JANGKA PENDEK
}

\author{
Setyo Karno Widigdo ${ }^{a}$
}

\begin{abstract}
ABSTRAK
Tulisan ini bertujuan untuk menelaah pengaturan serta mekanisme pelaksanaan koordinasi antar lembaga terkait pemberian Pinjaman Likuiditas Jangka Pendek (PLP) bagi Bank sebagai implikasi terbitnya UU No.2 Tahun 2020. Pandemi Corona Virus Disease (Covid-19) telah berdampak terhadap memburuknya sistem keuangan terutama berkaitan erat dengan meningkatnya risiko likuditas Bank sehingga perlui dimitigasi, salah satunya melalui pinjaman likuiditas jangka pendek atau pembiayaan likuiditas jangka pendek kepada BPR. Dalam penelitian ini penulis akan menggunakan metode normatif dengan pendekatan konseptual dan perundang-undangan. Hasil penelitian menunjukan bahwa kewenangan Bank Indonesia dalam memberikan PLP bagi Bank Sistemik dan Bank selain Bank Sistemik sebagai amanat UU No.2 Tahun 2020 merupakan penegasan atas kewenangan Bank Indonesia sebagaimana telah diatur dalam UU Pencegahan dan Penanganan Krisis Sistem Keuangan (UUPPKSK). Pengaturan pemberian PLP kepada Bank Umum telah diatur dalam Peraturan Bank Indonesia (PBI) yang telah mengakomodir kewenangan sebagaimana dalam UU PPKSK, namun belum terdapat pengaturan dan mekanisme pelaksanaan koordinasi antar lembaga terkait pemberian PLP kepada Bank Perkreditan Rakyat (BPR). Ketentuan yang masih berlaku sehubungan dengan fasilitas PLPP bagi BPR masih merujuk pada PBI No. 10/35/PBI/2008 tentang Fasilitas Pendanaan Jangka Pendek bagi Bank Perkreditan Rakyat dan PBI No. 11/29/PBI/2009 tentang Fasilitas Pendanaan Jangka Pendek Syariah bagi Bank Pembiayaan Rakyat Syariah. Pengaturan yang ada saat ini dinilai sudah tidak relevan dan memadai dalam rangka mengakomodir UU No. 2 Tahun 2020 dan tentunya UUPPKSK, juga mengingat telah beralihnya kewenangan pengawasan perbankan secara mikroprudensial kepada Otoritas Jasa Keuangan.
\end{abstract}

Kata kunci: otoritas jasa keuangan; pinjaman likuditas; pengaturan.

\section{ABSTRACT}

This paper aims to examine the arrangements and mechanisms for implementing inter-institutional coordination related to the provision of Liquidity Assistance (PLP) for Banks as the implications of the issuance of UU No.2 Tahun 2020. The Corona Virus Disease (Covid-19) pandemic has had an impact on the deterioration of the financial system, especially closely related to the increased liquidity risk, so it needs to be mitigated, one of which is through liquidity assistance or Sharia Liquidity Assistance to rural banks. In this study the authors use a normative method with a conceptual and statutory approach. Research shows that the authority of Bank Indonesia in providing PLJP for Systemic Banks and Banks other than Systemic Banks as mandated by PERPPU No.1 of 2020 is an affirmation of the authority of Bank Indonesia as stipulated in the Financial System Crisis Prevention and Management Act (UUPPKSK). The arrangement for granting PLIP to commercial banks has been regulated in a Bank Indonesia Regulation (PBI) that has accommodated the authority as stipulated in the UUPPKSK, but there is no regulation and mechanism for implementing coordination between institutions related to the granting of PLJP to Rural Banks (BPR). Provisions that still apply in relation to PLJP facilities for Rural Banks still refer to PBI No. 10/35/PBI/2008 concerning Liquidity Assistance for Rural Banks and PBI No. 11/29/PBI/2009 concerning Sharia Liquidity Assistance for Sharia Rural Banks. Existing regulations are considered to be irrelevant and insufficient in order to accommodate PERPPU No. 1 of 2020 and of course the UUPPKSK, also considering microprudential banking supervision authority has been transferred to the Financial Services Authority (OJK).

Keywords: liquidity assistance; otoritas jasa keuangan; regulatation. 


\section{PENDAHULUAN}

Pada awal tahun 2020, seluruh dunia dikejutkan dengan merebaknya wabah Corona Virus Disease 2019 (untuk selanjutnya disebut COVID-19). Peningkatan penyebaran, luas jangkauan, serta jumlah kasus wabah COVID-19 membuat World Heath Organization (WHO) sebagai organisasi kesehatan dunia meningkatkan derajat status dari epidemi menjadi pandemi pada sebagian besar negara-negara di seluruh dunia, termasuk di Indonesia.

Pandemi memiliki makna wabah yang berjangkit serempak di mana-mana, meliputi daerah geografi yang luas. ${ }^{1}$ Implikasi pandemi COVID-19 berdampak luas tidak hanya terhadap perlambatan pertumbuhan ekonomi nasional, juga terhadap penurunan penerimaan negara, peningkatan belanja negara serta pembiayaan. Implikasi Pandemi COVID-19 berdampak juga pada sistem keuangan dan kegiatan ekonomi domestik yang dirasakan seluruh sektor ekonomi Indonesia, tidak terkecuali sektor Usaha Mikro, Kecil dan Menengah (UMKM) yang merupakan salah sektor yang paling terdampak.

Untuk mencegah dan menangani dampak pandemi tersebut, pemerintah menerbitkan Peraturan Pemerintah Pengganti Undang-Undang (PERPPU) Nomor 1 Tahun 2020. Pada tanggal 16 Mei 2020, Perppu tersebut telah disahkan menjadi Undang-undang melalui UU No.2 Tahun 2020 tentang Penetapan Peraturan Pemerintah Pengganti Undang-Undangan No.1 Tahun 2020 tentang Kebijakan Keuangan Negara dan Stabilitas Sistem Keuangan Untuk Penanganan Pandemi Corona Virus Disease 2019 (Covid-19) dan/atau dalam Rangka Menghadapi Ancaman yang Membahayakan Perekonomian Nasional dan/atau Stabilitas Sistem Keuangan menjadi Undang-Undang.

Perkembangan penyebaran COVID-19 pada Industri Jasa Keuangan khususnya sektor perbankan telah berdampak secara langsung maupun tidak langsung terhadap kinerja dan kapasitas debitur dalam memenuhi kewajiban pembayaran kredit atau pembiayaan yang akan meningkatkan risiko kredit yang berpotensi mengganggu kinerja perbankan dan stabilitas sistem keuangan. Untuk mengakomodir UU No. 2 Tahun 2020 dan mempertimbangkan dampak COVID-19 pada sektor perbankan, Otoritas Jasa Keuangan menerbitkan Peraturan Otoritas Jasa Keuangan (selanjutnya disebut POJK) No.11/POJK.03/2020 tentang Stimulus Perekonomian Nasional sebagai Kebijakan Countercyclical dampak Penyebaran Coronavirus Disease 2019.

Pelaksanaan kebijakan penetapan kualitas dan restrukturisasi kredit sebagaimana POJK di atas, yang tidak memperhatikan prinsip kehati-hatian dan penerapan manajemen risiko akan mengakibatkan kesulitan pada Bank, salah satunya yaitu risiko likuiditas.

Dalam rangka menjaga stabilitas sistem keuangan di tengah-tengah kondisi terjadinya pandemi COVID-19 dan/atau untuk menghadapi ancaman krisis ekonomi dan/atau stabilitas sistem keuangan yang dipengaruhi oleh potensi risiko akibat kesulitan likuiditas Bank, berdasarkan

\footnotetext{
${ }^{1}$ Arti kata pandemi, <https://kbbi.web.id/pandemi>, [diakses pada 17/04/2020].
} 
ketentuan sebagaimana diatur dalam Pasal 16 ayat (1) huruf a PERPPU No. 1 Tahun 2020 Bank Indonesia sebagai Lender of the Last Resort (LoLR) diberikan kewenangan yang salah satunya untuk:

“Memberikan pinjaman likuiditas jangka pendek atau pembiayaan likuiditas jangka pendek berdasarkan prinsip syariah kepada Bank Sistemik atau bank selain Bank Sistemik".

Pelaksanaan salah satu kewenangan Bank Indonesia di atas dilakukan bersama Otoritas Jasa Keuangan dalam hal melakukan penilaian mengenai pemenuhan kecukupan agunan dan perkiraan kemampuan Bank Sistemik atau bank selain Bank Sistemik untuk mengembalikan pinjaman likuiditas jangka pendek atau pembiayaan likuiditas jangka pendek berdasarkan prinsip syariah. Sementara dalam hal penilaian mengenai pemenuhan persyaratan/kecukupan solvabilitas dan tingkat kesehatan Bank Sistemik atau bank selain Bank Sistemik dilakukan oleh Otoritas Jasa Keuangan.

Kewenangan Bank Indonesia sebagaimana Pasal 16 ayat (1) PERPPU No. 1 Tahun 2020 merupakan restatement dan penegasan atas kewenangan yang diberikan sebagaimana diatur dalam Pasal 20 ayat (1) juncto Pasal 30 Undang-Undang Nomor 9 Tahun 2016 tentang Pencegahan dan Penanganan Krisis Sistem Keuangan (selanjutnya disebut UU PPKSK) yang secara mutatis mutandis berlaku terhadap Bank selain Bank Sistemik.

Mengingat kewenangan untuk memberikan pinjaman likuiditas jangka pendek ada semenjak terbitnya UU PPKSK, Bank Indonesia telah memiliki pengaturan pemberian pinjaman likuiditas jangka pendek (selanjutnya disebut PLP) melalui Peraturan Bank Indonesia (selanjutnya disebut PBI) No. 22/05/PBI/2020 tentang Perubahan Kedua atas Peraturan Bank Indonesia No. 19/3/PBI/2017 tentang Pinjaman Likuiditas Jangka Pendek Bagi Bank Umum Konvensional dan PBI No. 22/6/PBI/2020 tentang Perubahan Kedua atas Peraturan Bank Indonesia Nomor 19/4/PBI/2017 tentang Pembiayaan Likuiditas Jangka Pendek Syariah bagi Bank Umum Syariah yang dinilai masih relevan untuk mengakomodir kewenangan Bank Indonesia sebagaimana diatur dalam PERPPU No. 1 Tahun 2020.

Termasuk dalam definisi Bank sebagaimana diatur dalam Pasal 1 Undang-Undang No. 10 Tahun 1998 tentang Perubahan Atas Undang-Undang Nomor 7 Tahun 1992 tentang Perbankan (selanjutnya disebut UU Perbankan) yaitu Bank Perkreditan Rakyat. Bank Perkreditan Rakyat (selanjutnya disebut BPR) adalah bank yang melaksanakan kegiatan usaha secara konvensional atau berdasarkan Prinsip Syariah yang dalam kegiatannya tidak memberikan jasa dalam lalu lintas pembayaran. ${ }^{2}$ BPR digolongkan sebagai Bank selain Bank Sistemik karena ukuran aset, modal dan kewajiban, luas jaringan atau kompleksitas transaksi atas jasa perbankan, serta keterkaitan dengan sektor keuangan lain dinilai tidak akan mengakibatkan gagalnya sebagian atau seluruh Bank lain atau

\footnotetext{
2 Pasal 1 Angka 4. Undang-Undang Nomor 10 Tahun 1998 tentang Perubahan Atas Undang-Undang Nomor 7 Tahun 1992 tentang Perbankan.
} 
sektor jasa keuangan, baik secara operasional maupun finansial sehingga termasuk dalam pengaturan sebagaimana dimaksud UUPPKSK dan PERPPU No.1 tahun 2020.

Hal yang menarik, sejak berlakunya UUPPKSK sampai dengan terbitnya PERPPU No.1 tahun 2020 belum terdapat pengaturan mengenai yang bersifat lebih khusus (lex specialist) dalam hal pemberian Pinjaman Likuiditas Jangka Pendek bagi Bank Perkreditan Rakyat Konvensional maupun Bank Pembiayaan Rakyat Syariah melalui Peraturan Bank Indonesia sebagaimana pengaturan yang telah ada bagi Bank Umum Konvensional.

Ketentuan yang masih berlaku sehubungan dengan fasilitas pinjaman/pendanaan likuditas jangka pendek (FPJP) bagi BPR masih merujuk pada Peraturan Bank Indonesia No. 10/35/PBI/2008 tentang Fasilitas Pendanaan Jangka Pendek bagi Bank Perkreditan Rakyat dan Peraturan Bank Indonesia No. 11/29/PBI/2009 tentang Fasilitas Pendanaan Jangka Pendek Syariah bagi Bank Pembiayaan Rakyat Syariah yang saat ini dinilai sudah tidak relevan dan memadai dalam rangka mengakomodir PERPPU NO. 1 Tahun 2020 dan tentunya UUPPKSK.

Berdasar penjelasan di atas, memunculkan pertanyaan bagaimana pengaturan dan mekanisme koordinasi antar lembaga terkait pemberian Pinjaman Likuiditas Jangka Pendek kepada Bank setelah berlakunya Peraturan Pemerintah Pengganti Undang-Undang (PERPPU) Nomor 1 Tahun 2020 ?

\section{METODE PENELITIAN}

Untuk menjawab pertanyaan di atas penulis menggunakan metode normatif dengan pendekatan peraturan perundang-undangan. Penulis mengggunakan konsep yang beranjak dari regulasi yang telah mengatur untuk mengungkap permasalahan, yaitu berdasarkan ketentuan PERPPU No.1 Tahun 2020, UU PPKSP, UU Bank Indonesia, UU Otoritas Jasa Keuangan, Peraturan Bank Indonesia, dan Peraturan Otoritas Jasa Keuangan. Sebagai bahan sekunder penulis menggunakan literatur berupa buku, jurnal, tulisan dari hasil karya ilmiah lainnya.

\section{PEMBAHASAN}

Kebijakan Pemerintah dalam Rangka Penyelamatan Perekonomian Nasional dan Stabilitas Sistem Keuangan sebagai Dampak Pandemi COVID-19.

Perkembangan penyebaran Corona Virus Disease 2019 (COVID-19) yang melanda dunia telah ditetapkan oleh Organisasi Kesehatan Dunia (World Health Organization) sebagai Pandemi pada sebagian besar negara-negara di seluruh dunia, termasuk Indonesia. Implikasi Pandemi COVID-19 tidak hanya berdampak pada perlambatan pertumbuhan ekonomi nasional, penurunan penerimaan negara, dan peningkatan belanja negara serta pembiayaan melainkan juga pada sistem keuangan 
Implikasi Hukum UU No. 2 Tahun 2020 Terhadap Pencegahan dan Penanganan Potensi Risiko Likuiditas Bank

dan kegiatan ekonomi domestik yang dirasakan seluruh sektor ekonomi Indonesia, tidak terkecuali sektor Usaha Mikro, Kecil dan Menengah (UMKM) yang merupakan salah sektor yang paling terdampak.

UMKM memiliki peranan yang cukup kuat dalam pembangunan ekonomi di Indonesia, karena sebagian besar jumlah penduduknya berpendidikan rendah dan hidup dalam kegiatan usaha kecil baik dalam sektor tradisional maupun modern. Peranan UMKM ini menjadi bagian yang diutamakan dalam setiap perancanaan tahapan pembangunan. ${ }^{3}$

Adapun penjabaran atas pengkategorian jenis usaha dapat dijabarkan sebagai berikut: ${ }^{4}$

1. Usaha Mikro adalah usaha produktif milik orang perorangan dan/atau badan usaha perorangan yang memenuhi kriteria memiliki kekayaan bersih paling banyak Rp50.000.000,00 (lima puluh juta rupiah) tidak termasuk tanah dan bangunan tempat usaha atau memiliki hasil penjualan tahunan paling banyak Rp300.000.000,00 (tiga ratus juta rupiah).

2. Usaha Usaha Kecil adalah usaha ekonomi produktif yang berdiri sendiri, yang dilakukan oleh orang perorangan atau badan usaha yang bukan merupakan anak perusahaan atau bukan cabang perusahaan yang dimiliki, dikuasai, atau menjadi bagian baik langsung maupun tidak langsung dari Usaha Menengah atau Usaha Besar yang memenuhi kriteria memiliki kekayaan bersih lebih dari Rp50.000.000,00 (lima puluh juta rupiah) sampai dengan paling banyak Rp500.000.000,00 (lima ratus juta rupiah) tidak termasuk tanah dan bangunan tempat usaha atau memiliki hasil penjualan tahunan lebih dari Rp300.000.000,00 (tiga ratus juta rupiah) sampai dengan paling banyak Rp2.500.000.000,00 (dua milyar lima ratus juta rupiah).

3. Usaha Menengah adalah usaha ekonomi produktif yang berdiri sendiri, yang dilakukan oleh orang perorangan atau badan usaha yang bukan merupakan anak perusahaan atau cabang perusahaan yang dimiliki, dikuasai, atau menjadi bagian baik langsung maupun tidak langsung dengan Usaha Kecil atau Usaha Besar yang memenuhi kriteria memiliki kekayaan bersih lebih dari Rp500.000.000,00 (lima ratus juta rupiah) sampai dengan paling banyak Rp10.000.000.000,00 (sepuluh milyar rupiah) tidak termasuk tanah dan bangunan tempat usaha atau memiliki hasil penjualan tahunan lebih dari Rp2.500.000.000,00 (dua milyar lima ratus juta rupiah) sampai dengan paling banyak Rp50.000.000.000,00 (lima puluh milyar rupiah).

Salah satu institusi keuangan yang berperan besar dalam aktivitas ekonomi adalah perbankan, yang berfungsi sebagai intermediary, yaitu institusi yang mempertemukan pihak yang kelebihan dana (surplus of fund) dan pihak yang kekurangan dana/membutuhkan dana (lack of fund).

\footnotetext{
3 Ade Pratiwi Susanty, "Perlindungan Hukum terhadap Kelangsungan Usaha Mikro, Kecil dan Menegah atas pemberlakuan masyarakat Ekonomi ASEAN", Jurnal Hukum Respublica, No.2 Vol.16, 2017, hlm. 319.

4 Pasal 1 angka 1, 2 dan 3 dan Pasal 6 UU 20 Tahun 2008 Tentang Usaha Mikro, Kecil, dan Menengah.
} 
Kehadiran perbankan dapat mengoptimalkan dana-dana yang ada agar dapat disalurkan kepada yang memerlukan, khususnya pelaku usaha untuk menggerakkan ekonomi. ${ }^{5}$

Bank adalah suatu badan usaha yang tugas utamanya sebagai lembaga perantara keuangan (financial intermediarie) yang menyalurkan dana dari pihak yang berkelebihan dana (idle fund surplus unit) kepada pihak yang membutuhkan dana atau kekurangan dana (deficit unit) pada waktu yang ditentukan. Bank adalah lembaga keuangan yang menjadi tempat bagi orang perseorangan, badanbadan usaha swasta, badan-badan usaha milik negara, bahkan lembaga-lembaga pemerintahan menyimpan dana-dana yang dimilikinya. ${ }^{6}$

Perbankan merupakan sektor yang menjadi parameter perekonomian negara bersama dengan pasar modal. Banks leading the development, besarnya peran perbankan dalam keseluruhan sistem keuangan nasional menuntut peran lebih dari sektor perbankan yang dapat memberdayakan ekonomi masyarakat guna mengawal pencapaian pertumbuhan ekonomi. Perbankan Indonesia mempunyai fungsi penting dalam aktivitas bisnis dan pembangunan ekonomi, khususnya sebagai lembaga intermediary. ${ }^{7}$ Hal itulah yang membuat Perbankan menjadi the most heavily regulated industry karena begitu takutnya pemerintah mendapati fakta bahwa terjadi guncangan pada sektor ini. Guncangnya sektor perbankan dikhawatirkan dapat membuat sektor-sektor lain turut terguncang, sehingga sedemikian rupa pemerintah mengusahakan kestabilan sektor ini. ${ }^{8}$

Berdasarkan pertimbangan implikasi dampak dan ancaman nyata COVID-19, Pemerintah mengambil langkah dan kebijakan dalam rangka penyelamatan perekonomian nasional dan stabilitas sistem keuangan melalui penerbitan PERPPU No. 1 Tahun 2020 tentang Kebijakan Keuangan Negara dan Stabilitas Sistem Keuangan untuk Penanganan Pandemi Corona Virus Disease 2019 (COVID-19) dan/atau dalam rangka menghadapi Ancaman yang Membahayakan Perekonomian Nasional dan/atau Stabilitas Sistem Keuangan (selanjutnya disebut PERPPU No. 1 Tahun 2020).

\section{Kebijakan Dibidang Perbankan dan Potensi Risiko Likuditas Bank Akibat Pandemi COVID-19}

Pada krisis tahun 1997-1998 yang lalu, sektor UMKM merupakan sektor yang risilience, sementara pada kondisi pandemi COVID-19 akan berbeda karena adanya kebijakan dan langkahlangkah penanganan pandemi COVID-19 berisiko pada ketidakstabilan makroekonomi dan sistem keuangan yang disebabkan pembatasan kegiatan usaha maupun aktivitas. Hal tersebut akan

\footnotetext{
5 Tri handayani dan Lastuti Abubakar, "Implikasi Kesepakatan ASEAN Banking Integration Framework (ABIF) terhadap Pembaruan Hukum Perbankan Indonesia", Rechtidee, No.2 Vol.11, Desember 2016, hlm. 141.

6 Hermansyah, Hukum Perbankan Nasional Indonesia, Kencana Prenada Media Group, Jakarta: 2013 hlm. 7.

7 Tri handayani dan Lastuti Abubakar, "Implikasi Kesepakatan ASEAN Banking Integration Framework (ABIF) terhadap Pembaruan Hukum Perbankan Indonesia, Op. Cit, hlm. 412.

8 Paripurna (et.al.), Peran Bank Sentral dalam Penanganan Permasalahan Likuiditas Bank; Isu Hukum dan tantangan pemberian/penyediaan Emergency Liquidity Assistance (ELA), Buletin Hukum Kebanksentralan: No. 2 Vol. 16, (Juli - Desember 2019, hlm. 187. <https://www.bi.go.id/id/publikasi/lain/hukum-kebanksentralan/Pages/buletinhukum_vol160219.aspx> [diakses pada $16 / 04 / 2020]$
} 
berpengaruh secara langsung ataupun tidak langsung terhadap kinerja dan kapasitas dalam memenuhi kewajiban pembayaran kredit atau pembiayaan debitur UMKM.

Berdasarkan data pada posisi 31 Desember 2019, portofolio kredit perbankan yang disalurkan pada sektor usaha mikro, kecil dan menengah (UMKM) sebesar Rp1.044.576 Miliar atau sebesar 18,24\% dari keseluruhan total kredit yang disalurkan oleh perbankan sebesar Rp5.725.776 Miliar. ${ }^{9}$ Jumlah tersebut menunjukan tingginya potensi dampak akibat pandemi COVID-19 sektor UMKM pada industri perbankan umumnya mengingat debitur sektor lain yang memperoleh kredit/pembiayaan turut terdampak meskipun dengan besaran yang lebih kecil. Sementara itu, terhadap BPR apabila kita melihat sejarah sejarah, terbentuknya BPR dimulai sejak zaman penjajahan Belanda diawali dengan berdirinya Bank Kredit Rakyat (BKR) dan Lumbung Desa, yang dibangun dengan tujuan membantu petani, pegawai, buruh, agar terlepas dari dari jeratan para rentenir yang membebani dengan bunga yang sangat tinggi. Pasca kemerdekaan Indonesia, Pemerintah mendorong pendirian bank-bank pasar yang terutama sangat terkenal karena didirikan di lingkungan pasar dan bertujuan untuk memberikan pelayanan jasa keuangan kepada pedagang pasar. Konsep BPR Indonesia sejalan dengan Grameen Bank atau Bank Desa yang merupakan model perbankan yang berasal dari Bangladesh yang didirikan oleh Muhammad Yunus yang profesinya sebagai pengajar ilmu ekonomi di Universitas Chittagong Bangladesh. Latar belakang berdirinya Grameen Bank dikarenakan ketidakpuasan atas sistem perbankan dan perkreditan yang ada di negaranya maupun di dunia yang pada dasarnya perbankan tidak ingin berhubungan dengan orang miskin, orang buta huruf dan kaum wanita. ${ }^{10}$ Tidak heran apabila dampak pandemi COVID-19 akan dirasakan sangat besar terhadap BPR karena mayoritas debitur dan nasabah BPR berada pada segmen UMKM sehingga angka persentase di atas akan berkali-kali lipat lebih besar pada BPR.

Pengaruh kinerja dan kapasitas debitur akan meningkatkan risiko kredit yang berpotensi mengganggu kinerja perbankan dan stabilitas sistem keuangan sehingga dapat mempengaruhi pertumbuhan ekonomi. Disamping itu, untuk mendorong optimalisasi kinerja perbankan khususnya fungsi intermediasi, menjaga stabilitas sistem keuangan, dan mendukung pertumbuhan ekonomi, Otoritas Jasa Keuangan selaku pemegang mandat pengaturan dan pengawasan terhadap lembaga perbankan berdasarkan kewenangannya menerbitkan Peraturan Otoritas Jasa Keuangan (selanjutnya disebut POJK) No.11/POJK.03/2020 tentang Stimulus Perekonomian Nasional sebagai Kebijakan Countercyclical dampak Penyebaran Coronavirus Disease 2019. Inti pengaturan dari POJK tersebut mengatur mengenai penerapan kebijakan perbankan untuk mendukung stimulus pertumbuhan ekonomi untuk debitur yang terkena dampak penyebaran COVID-19 termasuk debitur

\footnotetext{
9 Diolah oleh penulis dari Laporan Triwulanan, triwulan IV tahun 2019, Otoritas Jasa Keuangan. Jakarta: 2019.

${ }^{10}$ Pandu Suharto, Grameen Bank, Sebuah Model Bank untuk orang miskin di Bangladesh. Lembaga Pengembangan Perbankan Indonesia (LPPI), Jakarta: 1989, hlm. 38.
} 
usaha mikro, kecil, dan menengah melalui kebijakan penetapan kualitas aset dan kebijakan restrukturisasi kredit atau pembiayaan.

Restrukturisasi adalah upaya perbaikan yang dilakukan Bank dalam kegiatan perkreditan terhadap debitur yang mengalami kesulitan untuk memenuhi kewajibannya. ${ }^{11}$ Restrukturisasi oleh Bank Umum Konvensional dilakukan antara lain dengan cara:

1. Penurunan suku bunga Kredit.

2. Perpanjangan jangka waktu Kredit.

3. Pengurangan tunggakan pokok Kredit.

4. Pengurangan tunggakan bunga Kredit.

5. Penambahan fasilitas Kredit.

6. Konversi Kredit menjadi Penyertaan Modal Sementara.

Restrukturisasi kredit oleh BPR hanya dapat dilakukan melalui cara yang telah disebutkan dalam huruf a s.d. e. ${ }^{12}$ Sementara itu pelaksanaan restrukturisasi oleh Bank Umum Syariah dan Unit Usaha Syariah serta Bank Pembiayaan Rakyat Syariah masing-masing mengacu pada Peraturan Otoritas Jasa Keuangan No.16/POJK.03/2014 tentang Penilaian Kualitas Aset Bank Umum Syariah dan Unit Usaha Syariah sebagaimana telah diubah dengan Peraturan Otoritas Jasa No.19/POJK.03/2018 tentang Perubahan atas Peraturan Otoritas Jasa Keuangan No.16/POJK.03/2014 tentang Penilaian Kualitas Aset Bank Umum Syariah dan Unit Usaha Syariah dan Peraturan Otoritas Keuangan No.29/POJK.03/2019 tentang Kualitas Aset Produktif dan Pembentukan Penyisihan Penghapusan Aset Produktif Bank Pembiayaan Rakyat Syariah.

Pengaturan kebijakan penetapan kualitas aset dan kebijakan restrukturisasi kredit atau pembiayaan mengenai POJK No.11/POJK.03/2020 tentang Stimulus Perekonomian Nasional sebagai Kebijakan Countercyclical dampak Penyebaran Coronavirus Disease 2019 secara substansi menegasikan beberapa ketentuan pasal terutama mengenai penetapan kualitas kredit debitur, perlakuan akuntansi dan konsep one obligor dalam penyaluran dana sebagaimana diatur POJK tersebut pada paragraf sebelumnya. Perlakuan khusus tersebut bertujuan salah satunya untuk mendorong fungsi intermediasi dan pencegahan memburuknya tingkat kesehatan Bank secara massive dalam rangka menjaga stabilitas sistem keuangan.

Pelaksanaan kebijakan penetapan kualitas dan restrukturisasi kredit yang akan dilakukan oleh Bank harus dilakukan dengan senantiasa memperhatikan prinsip kehati-hatian dan penerapan manajemen risiko. Hal tersebut dilakukan salah satunya dalam rangka pengukuran dan pencegahan

\footnotetext{
11 Pasal 1 angka 25 Peraturan Otoritas Jasa Keuangan No. 40/POJK.03/2019 tentang Penilaian Kualitas Aset Bank Umum dan Pasal 1 angka 10 Peraturan Otoritas Jasa Keuangan No. 33/POJK.03/2018 tentang Kualitas Aktiva Produktif dan Pembentukan Penyisihan Penghapusan Aset Produktif BPR.

12 Lihat POJK No. 40/POJK.03/2019 2019 tentang Penilaian Kualitas Aset Bank Umum dan No. 33/POJK.03/2018 tentang Kualitas Aktiva Produktif dan Pembentukan Penyisihan Penghapusan Aset Produktif BPR.
} 
Implikasi Hukum UU No. 2 Tahun 2020 Terhadap Pencegahan dan Penanganan Potensi Risiko Likuiditas Bank

terhadap risiko yang mungkin timbul yang akan mengakibatkan kesulitan pada Bank, salah satunya yaitu risiko likuiditas.

Risiko Likuiditas adalah Risiko akibat ketidakmampuan Bank untuk memenuhi kewajiban yang jatuh tempo dari sumber pendanaan arus kas dan/atau aset likuid berkualitas tinggi yang dapat diagunkan, tanpa mengganggu aktivitas dan/atau kondisi keuangan Bank. Risiko likuiditas disebut juga sebagai risiko derajat kedua (second tier risk) karena sering ditimbulkan oleh risiko-risiko lainnya. Risiko ini terjadi karena adanya kesenjangan antara antara sumber pendanaan yang pada umumnya berjangka pendek dan kredit yang pada umumnya berjangka panjang (mismatch). Apabila kesenjangan tersebut cukup besar maka akan menurunkan kemampuan Bank untuk memenuhi kewajibannya pada saat jatuh tempo. Rendahnya kemampuan Bank dalam memenuhi kewajibanya akan berimbas pada kemampuan Bank untuk memenuhi semua penarikan dana oleh nasabah dan kewajiban yang telah jatuh tempo yang berakibat Bank tidak dapat mengembalikan dana tersebut. Dalam hal terjadi demikian, permasalahan tersebut dapat menyebabkan Bank mengalami kesulitan likuiditas dan berpotensi mengalami gagal bayar.

\section{Pengaturan dan Mekanisme Pinjaman Likuditas Jangka Pendek Setelah Berlakunya PERPPU No. 1} Tahun 2020.

Memperhatikan implikasi dampak COVID-19 yang dapat menyebabkan kesulitan likuditas Bank dan potensi krisis sistem keuangan, melalui Pasal 16 PERPPU No.1 Tahun 2020 kewenangan Bank Indonesia sebagai Bank Sentral untuk memberikan pinjaman likuiditas jangka pendek atau pembiayaan likuiditas jangka pendek berdasarkan prinsip syariah kepada Bank Sistemik atau bank selain Bank Sistemik ditegaskan kembali. Kewenangan Bank Indonesia tersebut merupakan restatement dan penegasan atas kewenangan yang telah diatur sebelumnya dalam UU PPKSK yang termuat dalam Pasal 20 ayat 1 dan Pasal 30:

Pasal 20 ayat 1 UU PPKSK, “Bank Sistemik yang mengalami kesulitan likuiditas dapat mengajukan permohonan kepada Bank Indonesia untuk mendapatkan pinjaman likuiditas jangka pendek atau pembiayaan likuiditas jangka pendek berdasarkan prinsip syariah."

Pasal 30 UU PPKSK, "Ketentuan mengenai pemberian pinjaman likuiditas jangka pendek atau pembiayaan likuiditas jangka pendek berdasarkan prinsip syariah sebagaimana dimaksud dalam Pasal 20 berlaku secara mutatis mutandis terhadap Bank selain Bank Sistemik."

Pada umumnya di berbagai negara, peranan Bank Sentral dalam sistem keuangan dan perekonomian, meliputi:

1. Mengontrol peredaran uang.

2. Menjaga stabilitas pasar uang dan pasar modal. 
3. Menjaga mekanisme pembayaran.

4. Mengawasi sistem perbankan.

5. Memberikan pinjaman terakhir (lender of the last resort/LoLR) atau bertindak sebagai bankir bank dalam negeri (banker's bank).

Kewenangan Bank Indonesia dalam memberikan pinjaman kepada Bank telah melekat pada Bank Indonesia sebagaimana ketentuan dalam Pasal 11 ayat 1 UU Bank Indonesia:

"Bank Indonesia dapat memberikan kredit atau pembiayaan berdasarkan Prinsip Syariah untuk jangka waktu paling lama 90 (sembilan puluh) hari kepada Bank untuk mengatasi kesulitan pendanaan jangka pendek Bank yang bersangkutan."

Fungsi bank sentral sebagai LoLR telah dikenal sejak akhir abad ke-19, khususnya ketika konsep LoLR pertama kali diperkenalkan oleh Henry Thornton pada tahun 1802 dan kemudian dikembangkan oleh Walter Bagehot pada tahun 1873, yang mendasarkan LoLR pada empat pilar yaitu: ${ }^{13}$

1. Bank sentral sebagai LoLR harus mencegah terjadinya kebangkrutan bank yang sehat akibat kekurangan likuiditas sementara.

2. Bank sentral harus memberikan pinjaman dengan bebas tetapi disertai dengan pengenaan penalty.

3. Bank sentral harus mengakomodir pihak yang memiliki jaminan (collateral) dengan nilai berkualitas tinggi.

4. Bank Sentral harus menyatakan kesiapannya memberikan pinjaman.

Titik krusial dari doktrin klasik Bagehot menegaskan bahwa peran LoLR berupa pemberian pinjaman kepada bank yang solvent but illiquid dengan kondisi tertentu. ${ }^{14}$ Terakit pelaksanaan fungsi LoLR, Thornton dan Bagehot menekankan adanya prinsip yang harus dipenuhi, yaitu adanya kondisi illiquid tapi solvent, jaminan dan penalty rate. Sebagian besar Bank Sentral di dunia mengatur bahwa pinjaman likuditas ditujukan unutk Bank dalam kondisi solven yang mengalami kesulitan likuiditas yang bersifat temporer. ${ }^{15}$

Sebagai pemegang fungsi LoLR, Bank Indonesia memiliki kewenangan sebagai pihak yang terakhir untuk memberikan pinjaman kepada bank termasuk dalam hal ini Bank yang mengalami kesulitan. Dengan kata lain Bank yang mengalami kesulitan likuiditas terlebih dahulu harus mencari bantuan dari sumber lain/perbankan sebelum ke Bank Sentral. Fungsi LoLR tersebut merupakan

\footnotetext{
${ }^{13}$ Zulkarnain Sitompul, Lembaga Penjamin Simpanan: Substansi dan Permasalahan, Books Terrace \& Library, Bandung: 2007, hlm. 125126.

${ }^{14}$ Jean Charles Rochet, "Coordination Failures and The Lender of Last Resort: Was Bagehot Right After All”, Journal of the European Economic Association, No.6, Vol.2, December 2004, hlm. 1118.

${ }^{15}$ Committee on the Global Financial System, "Designing frameworks for central bank liquidity assistance: addressing new challenges", CGFS Papers No. 58, April 2017. <https://www.bis.org/publ/cgfs58.htm>. [diakses pada 15/04/2020].
} 
Implikasi Hukum UU No. 2 Tahun 2020 Terhadap Pencegahan dan Penanganan Potensi Risiko Likuiditas Bank

bagian dari jaring pengaman keuangan (financial safety net) yang diperlukan dalam rangka memelihara stabilitas sistem keuangan. ${ }^{16}$

Kriteria Bank Sistemik dan Bank selain Bank Sistemik menjadi salah satu substansi pengaturan dalam PERPPU No.1 Tahun 2020 sebagaimana juga telah diatur melalui UU PPKSK. Menurut Pasal 1 Angka 5 UU PPKSK Bank Sistemik adalah:

"Bank yang karena ukuran aset, modal, dan kewajiban; luas jaringan atau kompleksitas transaksi atas jasa perbankan; serta keterkaitan dengan sektor keuangan lain dapat mengakibatkan gagalnya sebagian atau seluruh Bank lain atau sektor jasa keuangan, baik secara operasional maupun finansial, jika Bank tersebut mengalami gangguan atau gagal"

Sementara definisi Bank selain Bank Sistemik tidak dinyatakan pada PERRPU No.1 Tahun 2020 dan UU PPKSK, sehingga kita dapat merujuk pada Pasal 1 angka 3 Peraturan Lembaga Penjamin Simpanan (selanjutnya disebut PLPS) No.2 Tahun 2017 tentang Penyelesaian Bank selain Bank Sistemik yang mengalami Permasalah Solvabilitas adalah:

"Bank yang tidak ditetapkan sebagai Bank Sistemik sebagaimana dimaksud dalam UndangUndang mengenai Pencegahan dan Penanganan Krisis Sistem Keuangan."

Berdasarkan defisini mengenai Bank Sistemik dan Bank selain Bank Sistemik, BPR digolongkan sebagai Bank selain Bank Sistemik karena ukuran aset, modal dan kewajiban, luas jaringan atau kompleksitas transaksi atas jasa perbankan, serta keterkaitan dengan sektor keuangan lain dinilai tidak akan mengakibatkan gagalnya sebagian atau seluruh Bank lain atau sektor jasa keuangan, baik secara operasional maupun finansial.

Kewenangan Bank Indonesia dalam memberikan pinjaman likuditas sebagaimana amanat UU PPKSK menerapkan pendekatan baru dalam penanganan krisis sistem keuangan, yaitu dengan mengutamakan penggunaan sumber daya bank itu sendiri dan pendekatan bisnis tanpa menggunakan anggaran negara (bail in). Perubahan pendekatan dalam UU PPKSK yaitu bail-in dan keterkaitan dengan sistem keuangan (interconnectedness) ini menimbulkan implikasi hukum terhadap metode dan mekanisme pencegahan dan penanganan krisis sistem keuangan. Selain mewajibkan perbankan untuk memperkuat permodalan, penerapan prinsip bail-in akan mendorong bank untuk lebih mengedepankan prudential banking principle dalam setiap aktivitasnya sebagai upaya pencegahan kegagalan bank. ${ }^{17}$ Selain pendekatan bail in dan interconnectedness, Pasal 2 UU PPKSK meletakkan asas-asas dalam pencegahan dan penanganan krisis sistem keuangan yaitu asas kepentingan nasional; kemanfaatan; keadilan; keterpaduan; efektivitas; efisiensi; dan kepastian

\footnotetext{
${ }^{16}$ Paripurna (et.al.), Peran Bank Sentral dalam Penanganan Permasalahan Likuiditas Bank; Isu Hukum dan tantangan pemberian/penyediaan Emergency Liquidity Assistance (ELA), Op. Cit, hlm. 175.

${ }^{17}$ Lastuti Abubakar dan Tri Handayani, "Bail-In dan Interconnectedness: Isu Hukum Strategis Dalam Pencegahan Dan Penanganan Krisis Sistem Keuangan," Masalah-Masalah Hukum, No.4 Vol. 48, Oktober 2019, hlm. 413.
} 
hukum. Berdasarkan prinsip dan asas-asas tersebut, pencegahan dan penanganan krisis sistem keuangan diharapkan dapat dilakukan secara tepat berdasarkan kerja sama yang baik, terkoordinasi dan saling mendukung, yang pada akhirnya dapat bermanfaat bagi kepentingan bangsa, negara dan mewujudkan cita-cita kesejahteraan umum serta mengutamakan kepentingan bangsa, negara, dan masyarakat di atas kepentingan lainnya. ${ }^{18}$

Dalam pelaksanaan kewenangannya untuk mengakomodir amanat PERRPU No.1 Tahun 2020 dan UU PPKSK, Bank Indonesia telah memiliki pengaturan mengenai pemberian Pinjaman Likuiditas Jangka Pendek. Pinjaman likuiditas yang diberikan Bank Indonesia kepada Bank Umum dikenal dengan Pinjaman Likuiditas Jangka Pendek (PLP) dan Pembiayaan Likuditas Jangka Pendek Syariah (PLPS) sedangkan pinjaman yang diberikan kepada BPR dikenal dengan istilah Fasilitas Pendanaan Jangka Pendek (FPJP) dan Fasilitas Pendanaan Jangka Pendek Syariah (FPJPS).

Pemberian PLIP sebagai salah satu pelaksanaan fungsi LoLR oleh BI tersebut dapat dikaitkan dengan fungsi Bank Indonesia sebagai otoritas moneter ataupun sebagai otoritas makroprudensial. ${ }^{19}$ Pengaturan dalam pemberian PLJP kepada Bank Umum Konvensional dan PLPS Bank Umum Syariah masing-masing telah diatur dalam ketentuan Peraturan Bank Indonesia No. 22/05/PBI/2020 tentang Perubahan Kedua atas Peraturan Bank Indonesia No.19/3/PBI/2017 tentang Pinjaman Likuiditas Jangka Pendek Bagi Bank Umum Konvensional dan PBI No. 22/6/PBI/2020 tentang Perubahan Kedua atas Peraturan Bank Indonesia Nomor 19/4/PBI/2017 tentang Pembiayaan Likuiditas Jangka Pendek Syariah bagi Bank Umum Syariah.

Materi muatan pengaturan pemberian PLIP kepada Bank Umum Konvensional dan PLJPS kepada Bank Umum Syariah sebagaimana PBI di atas secara substansi telah meliputi pengaturan umum sebagai berikut:

1. Persyaratan PLP dan pemenuhan kelengkapan dokumen.

2. Jenis dan pemenuhan agunan.

3. Penilaian dan penggantian terhadap agunan.

4. Persetujuan, penolakan, penambahan dan penurunan plafon PLPP.

5. Larangan dan pembatasan kegiatan usaha.

6. Perhitungan Bunga/Bagi Hasil.

7. Pelunasan, Penyelesaian PLP dan eksekusi agunan.

8. Pelaporan, Pengawasan dan Pemeriksaan.

9. Sanksi atas pelanggaran.

\footnotetext{
${ }^{18} \mathrm{Ibid}, \mathrm{hlm} .415$.

${ }^{19}$ Fransiska Ari Indrawati, “Peranan Bank Indonesia Dalam Menjaga Stabilitas Sistem Keuangan: Telaahan Aspek Hukum”, Buletin Hukum Kebanksentralan, Volume 14, Nomor 1, (Januari-Juni 2017), hlm. 35. <https://www.bi.go.id/id/publikasi/lain/hukum kebanksentralan/Pages/buletinhukum_vol1417.aspx», [diakses pada 15/04/2020].
} 
Implikasi Hukum UU No. 2 Tahun 2020 Terhadap Pencegahan dan Penanganan Potensi Risiko Likuiditas Bank

Selain pentingnya pengaturan mengenai materi muatan pelaksanaan pemberian PLJP, ketentuan dimaksud telah memperhatikan peralihan kewenangan pengawasan perbankan secara mikroprudensial dari Bank Indonesia ke Otoritas Jasa Keuangan sebagaimana diatur dalam UU No.21 Tahun 2011 tentang Otoritas Jasa Keuangan sehingga dinilai masih relevan dan memadai sebagai landasan teknis dalam pemberian PLJP kepada Bank Umum.

Untuk pengaturan dalam pemberian FPJP kepada BPR Konvensional dan FPJPS BPR Syariah masing-masing diatur dalam ketentuan Peraturan Bank Indonesia No. 10/35/PBI/2008 tentang Fasilitas Pendanaan Jangka Pendek Bagi Bank Perkreditan Rakyat dan Peraturan Bank Indonesia No. 11/29/PBI/2009 tentang Fasilitas Pendanaan Jangka Pendek Syariah Bagi Bank Pembiayaan Rakyat Syariah.

Materi muatan pengaturan pemberian FPJP kepada BPR Konvensional dan FPJPS kepada BPR Syariah sebagaimana PBI di atas secara substansi telah meliputi pengaturan umum sebagaimana pengaturan terhadap Bank Umum. Namun hal krusial yang membedakan antara pemberian PLJP dan PLJPS kepada Bank Umum dan FPJP dan FPJPS kepada BPR yaitu materi muatan dan pengaturan pemberian FPJP dan FPJPS kepada BPR masih mengacu pada ketentuan lama sebelum peralihan kewenangan pengawasan perbankan secara mikroprudensial kepada Otoritas Jasa Keuangan. Selain itu, syarat pemenuhan kriteria BPR Konvensional yang dapat diberikan FPJP dalam Pasal 2 ayat (2) huruf b dan huruf c Peraturan Bank Indonesia No. 10/35/PBI/2008 tentang Fasilitas Pendanaan Jangka Pendek Bagi Bank Perkreditan Rakyat mengenai rata-rata Cash Ratio dan Rasio KPMM (Capital Adequacy Ratio) tidak memenuhi kondisi "solvent but illiquid" sebagaimana konsep pemberian pinjaman likuiditas jangka pendek oleh Bank Sentral yang juga telah diterapkan pada pengaturan PLP pada Bank Umum ${ }^{20}$. Pemenuhan kondisi "solven but illiquid" berkaitan erat dengan penilaian atas kemampuan BPR dalam pengembalian FPJS/FPJPS, sehingga ketentuan FPJP dan FPJPS dinilai sudah tidak relevan baik secara materil maupun formil. Oleh karena itu, terjadi kekosongan hukum atau setidaknya-setidaknya pemberian pinjaman likuditas jangka pendek kepada BPR Konvensional dan BPR Syariah sebagaimana amanat pelaksanaan PERRPU No.1 Tahun 2020 dan UU PPKSK tidak cukup memadai sehingga harus disesuaikan.

Ketiadaan peraturan perundang-undangan dan kebijakan pemerintah yang tidak mampu menahan kegagalan (failure) di sistem keuangan pun menjadi salah satu penyebab terjadinya krisis

\footnotetext{
${ }^{20}$ Sejak tanggal 1 Januari 2020, Otoritas Jasa Keuangan menetapkan BPR atau BPRS dalam pengawasan intensif (BDPI) sebagaimana dimaksud dalam Pasal 4 dalam hal BPR atau BPRS memenuhi kriteria: (a) rasio KPMM kurang dari 12\% (dua belas persen) namun sama dengan atau lebih dari $8 \%$ (delapan persen); (b). CR rata-rata selama 6 (enam) bulan terakhir kurang dari 5\% (lima persen) namun sama dengan atau lebih dari 4\% (empat persen); Pasal 5 ayat (2), Peraturan Otoritas Jasa Keuangan No. 19/POJK.03/2017 tentang Penetapan Status dan Tindak Lanjut Pengawasan Bank Perkreditan Rakyat dan Bank Pembiayaan Rakyat Syariah.
} 
tersebut. ${ }^{21}$ Dalam kasus collaps-nya Bank Northern Rock di Inggris, disinyalir bahwa satu di antara faktor penting yang menyebabkannya adalah kurangnya regulasi terkait penanganan likuiditas yang memadai. $^{22}$

Koordinasi antara Bank Indonesia dan Otoritas Jasa Keuangan maupun lembaga lain dalam rangka pelaksanaan fungsi, tugas dan kewenangan masing-masing secara umum telah diatur dalam Pasal 41 UU Otoritas Jasa Keuangan dengan cakupan sebagai berikut:

(1) OJK menginformasikan kepada Lembaga Penjamin Simpanan mengenai bank bermasalah yang sedang dalam upaya penyehatan oleh OJK sebagaimana dimaksud dalam peraturan perundangundangan.

(2) Dalam hal OJK mengindikasikan bank tertentu mengalami kesulitan likuiditas dan/atau kondisi kesehatan semakin memburuk, OJK segera menginformasikan ke Bank Indonesia untuk melakukan langkah-langkah sesuai dengan kewenangan Bank Indonesia.

Dalam rangka pemberian PLP koordinasi antara Bank Indonesia dan Otoritas Jasa Keuangan diatur dalam Pasal 17 ayat (1) PERRPU No.1 Tahun 2020 sebagai berikut:

"Dalam pemberian pinjaman likuiditas jangka pendek atau pembiayaan likuiditas jangka pendek berdasarkan prinsip syariah oleh Bank Indonesia sebagaimana dimaksud dalam Pasal 16 ayat (1) huruf a:

a. Otoritas Jasa Keuangan melakukan penilaian mengenai pemenuhan persyaratan/kecukupan solvabilitas dan tingkat kesehatan Bank Sistemik atau bank selain Bank Sistemik.

b. Bank Indonesia bersama Otoritas Jasa Keuangan melakukan penilaian mengenai pemenuhan kecukupan agunan dan perkiraan kemampuan Bank Sistemik atau bank selain Bank Sistemik untuk mengembalikan pinjaman likuiditas jangka pendek atau pembiayaan likuiditas jangka pendekberdasarkan prinsip syariah."

Berdasarkan Pasal 28 angka 11 PERRPU No.1 Tahun 2020, pengaturan koordinasi antara Bank Indonesia dan Otoritas Jasa Keuangan yang telah diatur dalam Pasal 20 ayat (2) UUPPKSK dinyatakan tidak berlaku sepanjang berkaitan dengan kebijakan keuangan negara untuk penanganan penyebaran Corona Virus Disease 2019 (COVID-19) dan/atau dalam rangka menghadapi ancaman yang membahayakan perekonomian nasional dan/atau stabilitas sistem keuangan.

Bank Indonesia sebagai bagian penting dalam pemberian PLJP dan PLJPS telah memiliki pengaturan dalam No. 22/05/PBI/2020 tentang Perubahan Kedua atas Peraturan Bank Indonesia No.

\footnotetext{
${ }^{21}$ Moreno (et.al.), "Asia's Financial Crisis: Lessons and Policy Responses", Working Paper PB98-02, Center for Pacific Basin Monetary and Economic Studies, Federal Reserve Bank of San Francisco, (1998), hlm. 2, <https://econpapers.repec.org/paper/fipfedfpb/98-02.htm>. [diakses pada 14/04/2020].

22 Emilios Avgouleas, "Banking Supervision and The Special Resolution Regime of the Banking Act 2009: The Unfinished Reform", Capital Markets Law Journal, No.2 Vol.4, April 2009, hlm. 202.
} 
Implikasi Hukum UU No. 2 Tahun 2020 Terhadap Pencegahan dan Penanganan Potensi Risiko Likuiditas Bank

19/3/PBI/2017 tentang Pinjaman Likuiditas Jangka Pendek Bagi Bank Umum Konvensional dan PBI No. 22/6/PBI/2020 tentang Perubahan Kedua atas Peraturan Bank Indonesia Nomor 19/4/PBI/2017 tentang Pembiayaan Likuiditas Jangka Pendek Syariah bagi Bank Umum Syariah mengenai mekanisme koordinasi yang lebih khusus dalam rangka pelaksanaan kewenangannya yang memerlukan koordinasi dengan lembaga terkait.

Bentuk koordinasi yang dilakukan Bank Indonesia dan Otoritas Jasa Keuangan tercermin dalam hal sebagai berikut:

1. Permintaan penilaian terkait pemenuhan persyaratan/kecukupan solvabilitas dan tingkat kesehatan Bank dan pelaksanaan bersama mengenai pemenuhan kecukupan agunan dan perkiraan kemampuan Bank untuk mengembalikan PLP. ${ }^{23}$

2. Penyampaian laporan daftar aset kredit / pembiayaan. ${ }^{24}$

3. Permohonan PLJP. ${ }^{25}$

4. Penyampaian hasil persetujuan dan penolakan PLP. ${ }^{26}$

5. Perpanjangan jangka waktu, penambahan dan penurunan plafon PLP. ${ }^{27}$

6. Larangan dan Pembatasan kegiatan bagi bank penerima PLJP. ${ }^{28}$

7. Eksekusi agunan. ${ }^{29}$

8. Pelaporan, Pengawasan dan Pemeriksaan. ${ }^{30}$

9. Pengenaan Sanksi. ${ }^{31}$

Namun demikian, dalam pemberian FPJP dan FPJPS kepada BPR sebagaimana Peraturan Bank Indonesia No. 10/35/PBI/2008 tentang Fasilitas Pendanaan Jangka Pendek Bagi Bank Perkreditan Rakyat dan Peraturan Bank Indonesia No. 11/29/PBI/2009 tentang Fasilitas Pendanaan Jangka Pendek Syariah Bagi Bank Pembiayaan Rakyat Syariah sama sekali tidak terdapat pengaturan mekanisme dan koordinasi dengan lembaga terkait yang dalam hal ini Otoritas Jasa Keuangan, hal ini disebabkan karena 2 (dua) ketentuan pengaturan terhadap BPR tersebut belum memperhatikan

\footnotetext{
${ }^{23}$ Lihat Pasal 10, Peraturan Bank Indonesia No. 22/05/PBI/2020 tentang Perubahan Kedua atas Peraturan Bank Indonesia No. 19/3/PBI/2017 tentang Pinjaman Likuiditas Jangka Pendek Bagi Bank Umum Konvensional.

${ }^{24}$ Lihat Pasal 6 ayat 2, Peraturan Bank Indonesia No. 22/05/PBI/2020 tentang Perubahan Kedua atas Peraturan Bank Indonesia No. 19/3/PBI/2017 tentang Pinjaman Likuiditas Jangka Pendek Bagi Bank Umum Konvensional.

${ }^{25}$ Lihat Pasal 8, Peraturan Bank Indonesia No. 22/05/PBI/2020 tentang Perubahan Kedua atas Peraturan Bank Indonesia No. 19/3/PBI/2017 tentang Pinjaman Likuiditas Jangka Pendek Bagi Bank Umum Konvensional.

${ }^{26}$ Lihat Pasal 11 ayat (3), Peraturan Bank Indonesia No. 22/05/PBI/2020 tentang Perubahan Kedua atas Peraturan Bank Indonesia No. 19/3/PBI/2017 tentang Pinjaman Likuiditas Jangka Pendek Bagi Bank Umum Konvensional.

${ }^{27}$ Lihat Pasal 16 ayat (1), Pasal 18 ayat (1) dan (3), Pasal 20 ayat (1), Peraturan Bank Indonesia No. 22/05/PBI/2020 tentang Perubahan Kedua atas Peraturan Bank Indonesia No. 19/3/PBI/2017 tentang Pinjaman Likuiditas Jangka Pendek Bagi Bank Umum Konvensional.

${ }^{28}$ Lihat Pasal 21 ayat (2), Peraturan Bank Indonesia No. 22/05/PBI/2020 tentang Perubahan Kedua atas Peraturan Bank Indonesia No. 19/3/PBI/2017 tentang Pinjaman Likuiditas Jangka Pendek Bagi Bank Umum Konvensional.

${ }^{29}$ Lihat Pasal 27 ayat (1), Peraturan Bank Indonesia No. 22/05/PBI/2020 tentang Perubahan Kedua atas Peraturan Bank Indonesia No. 19/3/PBI/2017 tentang Pinjaman Likuiditas Jangka Pendek Bagi Bank Umum Konvensional.

30 Lihat Pasal 29 ayat (1), Pasal 30 ayat (1), Pasal 31 ayat (2), Peraturan Bank Indonesia No. 22/05/PBI/2020 tentang Perubahan Kedua atas Peraturan Bank Indonesia No. 19/3/PBI/2017 tentang Pinjaman Likuiditas Jangka Pendek Bagi Bank Umum Konvensional.

${ }^{31}$ Lihat Pasal 33, Peraturan Bank Indonesia No. 22/05/PBI/2020 tentang Perubahan Kedua atas Peraturan Bank Indonesia No. 19/3/PBI/2017 tentang Pinjaman Likuiditas Jangka Pendek Bagi Bank Umum Konvensional.
} 
peralihan tugas, fungsi dan kewenangan pengawasan perbankan secara mikroprudensial dari Bank Indonesia kepada Otoritas Jasa Keuangan.

Baik dalam PLIP kepada Bank Umum maupun FPJP dan FPJPS kepada BPR, belum terdapat suatu implementasi berupa kesepakatan pengaturan yang mengatur hal-hal yang bersifat lebih teknis yang mengharmonisasikan fungsi, tugas, kewenangan maupun pengaturan internal masingmasing lembaga sebagai bentuk pelaksanaan koordinasi dalam rangka meningkatkan efektivitas dan optimalisasi peran masing-masing lembaga yang dituangkan dalam bentuk nota kesepahaman (Memorandum of Undestanding) antar lembaga seperti yang sudah umum dilakukan dalam praktik kerjasama antar lembaga.

\section{PENUTUP}

Berdasarkan pembahasan di atas dapat diketahui bahwa, dalam rangka pencegahan dan penanganan potensi risiko likuiditas jangka pendek Bank salah satu solusi yang dapat dipergunakan yaitu melalui mekanisme pemberian pinjaman likuiditas jangka pendek. Pemberian pinjaman likuiditas jangka pendek bagi Bank Umum dikenal dengan PLP dan PLPS sementara pada BPR dikenal dengan FPJP dan FPJPS.

Bank Indonesia selaku pemegang LoLR telah mempunyai ketentuan yang mengatur mengenai pemberian PLJP bagi Bank Umum melalui Peraturan Bank Indonesia No. 22/05/PBI/2020 tentang Perubahan Kedua atas Peraturan Bank Indonesia No. 19/3/PBI/2017 tentang Pinjaman Likuiditas Jangka Pendek Bagi Bank Umum Konvensional dan Peraturan Bank Indonesia Nomor 22/6/PBI/2020 tentang Perubahan Kedua atas Peraturan Bank Indonesia Nomor 19/4/PBI/2017 tentang Pembiayaan Likuiditas Jangka Pendek Syariah bagi Bank Umum Syariah yang dinilai masih relevan dalam mengakomodir amanat sebagaimana PERRPU No. 1 Tahun 2020. Pengaturan dalam PBI tersebut telah mencakup aspek koordinasi kelembagaan antara Bank Indonesia dan Otoritas Jasa Keuangan dalam pelaksanaannya. Sementara itu, pengaturan mengenai pemberian PLPP kepada BPR Konvensional dan BPR Syariah sampai saat ini masih diatur dalam ketentuan Peraturan Bank Indonesia No. 10/35/PBI/2008 tentang Fasilitas Pendanaan Jangka Pendek Bagi Bank Perkreditan Rakyat dan Peraturan Bank Indonesia No. 11/29/PBI/2009 tentang Fasilitas Pendanaan Jangka Pendek Syariah Bagi Bank Pembiayaan Rakyat Syariah. Landasan pengaturan pemberian pinjaman likuditas jangka pendek kepada BPR secara materil dan formil dinilai sudah tidak relevan dalam mengakomodir kewenangan Bank Indonesia sebagaimana diamanatkan PERRPU No.1 Tahun 2020. Hal ini mengakibatkan kekosongan hukum atas pengaturan dan mekanisme koordinasi dalam pemberian pinjaman likuiditas jangka pendek kepada BPR. 
Implikasi Hukum UU No. 2 Tahun 2020 Terhadap Pencegahan dan Penanganan Potensi Risiko Likuiditas Bank

Dalam pemberian PLJP kepada Bank Umum maupun FPJP dan FPJPS kepada BPR, belum terdapat suatu implementasi berupa kesepakatan pengaturan yang mengatur hal-hal yang bersifat lebih teknis yang mengharmonisasikan fungsi, tugas, kewenangan maupun pengaturan internal masing-masing lembaga sebagai bentuk pelaksanaan koordinasi dalam rangka meningkatkan efektivitas dan optimalisasi peran masing-masing lembaga yang dituangkan dalam bentuk Nota Kesepahaman (Memorandum of Undestanding) antar lembaga seperti yang sudah umum dilakukan dalam praktik kerjasama antar lembaga.

\section{DAFTAR PUSTAKA}

\section{Buku}

Hermansyah, Hukum Perbankan Nasional Indonesia, Kencana Prenada Media Group, Jakarta: 2013. Pandu Suharto, Grameen Bank, Sebuah Model Bank untuk orang miskin di Bangladesh. Lembaga Pengembangan Perbankan Indonesia LPPI, Jakarta: 1989.

Zulkarnain Sitompul, Lembaga Penjamin Simpanan: Substansi dan Permasalahan, Books Terrace \& Library, Bandung: 2007.

\section{Jurnal}

Ade Pratiwi Susanty, "Perlindungan Hukum terhadap Kelangsungan Usaha Mikro, Kecil dan Menegah atas pemberlakuan masyarakat Ekonomi ASEAN", Jurnal Hukum Respublica, No.2 Vol.16, 2017.

Emilios Avgouleas, "Banking supervision and the special resolution regime of the Banking Act 2009: the unfinished reform", Capital Markets Law Journal, No.2 Vol.4, April 2009.

Jean Charles Rochet, "Coordination Failures and The Lender of Last Resort: Was Bagehot Right After All", Journal of the European Economic Association, No.6, Vol. 2, December 2004.

Lastuti Abubakar dan Tri Handayani, "Bail-In dan Interconnectedness: Isu Hukum Strategis Dalam Pencegahan Dan Penanganan Krisis Sistem Keuangan," Masalah-Masalah Hukum, No.4 Vol. 48, Oktober 2019.

Tri Handayani dan Lastuti Abubakar, "Implikasi Kesepakatan ASEAN Banking Integration Framework (ABIF) terhadap Pembaruan Hukum Perbankan Indonesia", Rechtidee, No.2 Vol.11, Desember 2016. 


\section{Peraturan Perundang-Undangan}

Undang-Undang Nomor 2 Tahun 2020 tentang Penetapan Peraturan Pemerintah Pengganti UndangUndang Republik Indonesia Nomor 1 Tahun 2020 tentang Kebijakan Keuangan Negara dan Stabilitas Sistem Keuangan untuk Penanganan Pandemi Corona Virus Disease 2019 (COVID19) dan/atau dalam rangka Menghadapi Ancaman yang Membahayakan Perekonomian Nasional dan/atau Stabilitas Sistem Keuangan menjadi Undang-Undang.

Undang-Undang Republik Indonesia Nomor 9 Tahun 2016 tentang Pencegahan Dan Penanganan Krisis Sistem Keuangan.

Undang-Undang Republik Indonesia Nomor 21 Tahun 2011 tentang Otoritas Jasa Keuangan.

Undang-Undang Republik Indonesia Nomor 7 Tahun 2009 tentang Penetapan Peraturan Pemerintah

Pengganti Undang-Undang Nomor 3 Tahun 2008 Tentang Perubahan Atas Undang-Undang Nomor 24 Tahun 2004 Tentang Lembaga Penjamin Simpanan Menjadi Undang-Undang.

Undang-Undang Republik Indonesia Nomor 6 Tahun 2009 tentang Penetapan Peraturan Pemerintah

Pengganti Undang-Undang Nomor 2 Tahun 2008 Tentang Perubahan Kedua Atas Undangundang Nomor 23 Tahun 1999 Tentang Bank Indonesia Menjadi Undang-Undang.

Undang-Undang Republik Indonesia Nomor 20 Tahun 2008 Tentang Usaha Mikro, Kecil, Dan Menengah.

Undang-Undang Republik Indonesia Nomor 10 Tahun 1998 tentang Perubahan Atas Undang-Undang Nomor 7 Tahun 1992 Tentang Perbankan.

Peraturan Bank Indonesia No. 22/05/PBI/2020 tentang Perubahan Kedua atas Peraturan Bank Indonesia No. 19/3/PBI/2017 tentang Pinjaman Likuiditas Jangka Pendek Bagi Bank Umum Konvensional.

Peraturan Bank Indonesia Nomor 22/6/PBI/2020 tentang Perubahan Kedua atas Peraturan Bank Indonesia Nomor 19/4/PBI/2017 tentang Pembiayaan Likuiditas Jangka Pendek Syariah bagi Bank Umum Syariah

Peraturan Otoritas Jasa Keuangan Nomor 40/POJK.03/2019 tentang Penilaian Kualitas Aset Bank Umum.

Peraturan Otoritas Jasa Keuangan Nomor 33/POJK.03/2018 tentang Kualitas Aktiva Produktif dan Pembentukan Penyisihan Penghapusan Aset Produktif BPR.

Peraturan Otoritas Jasa Keuangan Nomor 19 /POJK.03/2017 tentang Penetapan Status dan Tindak Lanjut Pengawasan Bank Perkreditan Rakyat dan Bank Pembiayaan Rakyat Syariah.

Peraturan Otoritas Jasa Keuangan Nomor 12/POJK.03/2016 tentang Kegiatan Usaha Dan Wilayah Jaringan Kantor Bank Perkreditan Rakyat Berdasarkan Modal Inti. 
Implikasi Hukum UU No. 2 Tahun 2020 Terhadap Pencegahan dan Penanganan Potensi Risiko Likuiditas Bank

Peraturan Otoritas Jasa Keuangan Nomor 13/POJK.03/2015 tentang Penerapan Manajemen Risiko Bagi Bank Perkreditan Rakyat.

Peraturan Otoritas Jasa Keuangan Nomor 20/POJK.03/2014 tentang Bank Perkreditan Rakyat.

Peraturan Bank Indonesia Nomor 11/29/PBI/2009 tentang Fasilitas Pendanaan Jangka Pendek Syariah bagi Bank Pembiayaan Rakyat Syariah.

Peraturan Bank Indonesia Nomor 10/35/PBI/2008 tentang Fasilitas Pendanaan Jangka Pendek bagi Bank Perkreditan Rakyat.

\section{Sumber Lain}

Arti kata pandemi, <https://kbbi.web.id/pandemi>, [diakses pada 17/04/2020].

Fransiska Ari Indrawati, "Peranan Bank Indonesia Dalam Menjaga Stabilitas Sistem Keuangan: Telaahan Aspek Hukum”, Buletin Hukum Kebanksentralan, No. 1 Vol. 14, Januari-Juni 2017: 142. <https://www.bi.go.id/id/publikasi/lain/hukum-kebanksentralan/Pages/buletinhukum_ vol1417.aspx>, [diakses pada 15/04/2020].

Committee on the Global Financial System, "Designing frameworks for central bank liquidity assistance: addressing new challenges", CGFS Papers No. 58, April 2017. <https://www.bis.org/publ/cgfs58.htm>, [diakses pada 15/04/2020].

Moreno (et.al.), “Asia's Financial Crisis: Lessons and Policy Responses", Working Paper PB98-02, Center for Pacific Basin Monetary and Economic Studies, Federal Reserve Bank of San Francisco, (1998). <https://econpapers.repec.org/paper/fipfedfpb/98-02.htm>, [diakses pada 14/04/2020].

Paripurna, Irna Nurhayati, Very Antoni, Karina Dwi Nugrahati Putri, Muhammad Fatahillah Akbar, Dyah Pratiwi, Dadang Arief Kusuma, , Ellia Syahrini, Nurtjipto, dan Andy Savanto, "Peran Bank Sentral dalam Penanganan Permasalahan Likuiditas Bank; Isu Hukum dan tantangan pemberian/penyediaan Emergensy Liquidity Assistance (ELA)", Buletin Hukum Kebanksentralan, Volume 16, Nomor 2, (Juli-Desember 2019): 173-203. <https://www.bi.go.id/id/publikasi/lain/hukum-kebanksentralan/Pages/buletinhukum_ vol160219.aspx>, [diakses pada 16/04/2020]. 